\title{
IGKV1D-13 wt Allele
}

National Cancer Institute

\section{Source}

National Cancer Institute. IGKV1D-13 wt Allele. NCI Thesaurus. Code C117124.

Human IGKV1D-13 wild-type allele is located in the vicinity of 2p11.2 and is approximately Z kb in length. This allele, which encodes Ig kappa chain V-I region D-13 protein, plays a role in immunoglobulin epitope specificity. 